\title{
ВІДТВОРЕННЯ ПРАГМАТИКИ ФРАЗЕОЛОГІЗМІВ В АНГЛО-УКРАЇНСЬКОМУ ПЕРЕКЛАДІ ПРОМОВ Г. КЛІНТОН
}

Стаття присвячена питанню перекладу фразеологічних одиниць у промовах Г. Клінтон. Схарактеризовано фразеологізми як мовні одиниці, що забезпечують прагматику промов і потребують особливої уваги перекладача, його обізнаності, досвіду та досконалих знань як іноземної мови, так і мови перекладу. У дослідженні виокремлено фразеологічні одинииі в промовах Г. Клінтон, обгрунтовано доцільність використання конкретних способів їх перекладу, що є найбільш доречними для відтворення емоційно-експресивного забарвлення оригінальних текстів.

Ключові слова: фразеологічні одиниці, прагматика, спосіб перекладу, емоційно-експресивне забарвлення, промова.

Karpenko N., Kudriavtseva A. Rendering Pragmatics of Phraseologial Units in English-Ukrainian Translation of $\mathbf{H}$. Clinton's Speeches. The article is devoted to the study of phraseologial units that are identified in speeches of H. Clinton. A phraseologial unit is viewed as an object of study that accumulates cultural features of a particular nation, represents its traditions and reflects its national identity. Hence, translation of these units is a challenging task due to the fact that translation language does not provide the units that are able to render exactly the same pragmatics that the original set phrases have.

The relevance of the topic results from modern tendencies of the development of translation studies. Moreover, the problem of phraseological units transaltion and rendering their pragmatics into another language is the one which requires further and more painstaking work, regarding its complex nature and lack of comprehensive studies.

The aim of the research is to determine means of phraseological units translation in Hillary Clinton's speeches into Ukrainian and motivate the relevance of their usage.

The aim results in solving the tasks as follows: 1) to define means of phraseological units transaltion; 2) to find out phraseological units in H. Clinton's speeches that provide their pragmatics; 3) to characterise and motivate the relevance of usage of particular translation means for rendering pragmatics of the phraseological units.

The means of translation of phraseological units in Hillary Clinton's speeches were analysed in terms of rendering their emotional and expressive charge into the Ukrainian language. The usage of phraseological and non-phraseological translation was illustrated by the examples from the speeches. Such means of translation as analogues, lexical translation and usage of metaphors were applied for rendering the pragmatics of the original texts. 
Key words: phraseological units, emotional and expressive charge, pragmatics, means of translation, speech.

\section{Вступ}

Фразеологічні одиниці - втілення та віддзеркалення національної ідентичності й неповторності, ключ для розуміння менталітету, традицій, цінностей конкретної нації. Здавна ці знаки культури акумулювали душу й дух народу та є важливими для сприйняття певного етносу в процесі міжкультурної комунікації. Фразеологізми - це спосіб відтворення національної ідентичності, вони є цінним джерелом знань про культуру, традиції, менталітет, гастрономічні вподобання, географічне положення конкретної нації. Їхньою визначальною рисою $є$ емоційно-експресивне навантаження, відтворення якого $є$ необхідним під час перекладу. Природнім $є$ той факт, що переклад цих мовних одиниць іноземною мовою є якщо не неможливим, то складним, оскільки часто не вдається знайти еквіваленти або ж аналоги в мові перекладу.

Завдання перекладача - досягнення адекватного перекладу, що можливий за умови використання для цього оптимального способу, наприклад, шляхом використання фразеологізму з ідентичним значенням; у цьому разі експресивність не втрачається, однак такі випадки не є частотними, тому перекладачеві необхідно звертатися до інших способів вирішення проблеми відтворення прагматики фразеологізмів.

У межах перекладознавства питанню особливостей відтворення прагматики фразеологізмів присвячені дослідження таких науковців, як В. Виноградов, Р. Зорівчак, В. Коміссаров, С. Кузьмін, О. Кунін, О. Чередниченко, В. Гак та інші.

Актуальність дослідження зумовлена сучасними тенденціями розвитку перекладознавства з фокусом на переклад фразеологізмів. Окрім того, проблема перекладу фразеологічних одиниць $є$ однією з таких, що потребує подальшої і більш детальної розробки, зважаючи на ії складність та недостатню кількість вичерпних розвідок у відповідному напрямку.

Мета дослідження - виявити способи перекладу фразеологічних одиниць у промовах Г. Клінтон, обгрунтувати доцільність їх використання. Визначена мета зумовлює виконання таких завдань: 
1) визначити способи перекладу фразеологічних одиниць; 2) виокремити фразеологічні одиниці в промовах Г. Клінтон, що забезпечують ï прагматику; 3) схарактеризувати та обгрунтувати доцільність використання запропонованих способів перекладу для відтворення прагматики оригіналу.

\section{Методи дослідження}

Для досягнення мети використано такі методи дослідження: метод цілеспрямованої вибірки для виокремлення фразеологічних одиниць; для визначення семантичної структури й виявлення найбільш доцільних способів перекладу - методи когнітивного, прагматичного аналізу та описовий метод.

\section{Виклад основного матеріалу}

Теорія перекладу фразеологізмів не є усталеною й однозначною, а способи перекладу, що їх пропонують лінгвісти, різняться та потребують більш усталеної структури. Перекладознавці пропонують різні варіанти відтворення: за допомогою еквівалентів, аналогів, калькування, контекстуальний переклад; О. Кунін пропонує комбінований, обертональний переклади (Кунин, 1964) та ін. Очевидно, що така природна неоднозначність $€$ наслідком структурно-семантичних особливостей фразеологічних одиниць, що складно зберегти під час перекладу. Однак, беручи до уваги наявні способи, можна виокремити фразеологічний переклад - використання еквівалентів й аналогів та нефразеологічний, коли вдаються до інших мовних засобів у разі відсутності попередніх.

У процесі фразеологічного перекладу йдеться про пошук абсолютного або часткового еквівалента або ж аналога. Використання еквівалента є можливим за умови, що фразеологічні одиниці походять $з$ одного джерела, $є$ інтернаціональними. Для використання повного та часткового аналога необхідна наявність у мові перекладу фразеологічної одиниці, що є близькою в конотативному значенні до оригіналу.

До нефразеологічного перекладу зараховують лексичний, коли фразеологічну одиницю відтворюють словом, тотожним іiі значенню. Цей переклад не можна вважати повноцінним, навіть ураховуючи можливість компенсації в контексті, оскільки неможливо 
не втратити експресивності, конотації, афористичності, що могли 6 бути відтворені лише фразеологізмом. Перекладачі також удаються до калькування, що є виправданим лише в тому разі, коли дослівний переклад фразеологізму може донести до читача оригінальний зміст повідомлення, зберегти метафоричність. Ще одним можливим способом перекладу фразеологізмів $є$ описовиц̆, що є тлумаченням фразеологічні одиниці.

Звертаємо увагу на класифікацію С. Кузьміна (Subbotina), який виокремлює переклад за допомогою метафори, що дає змогу зберегти образність фразеологізму. Цей спосіб видається досить ефективним за умови відсутності еквівалента чи аналога, оскільки забезпечує відтворення образності й емоційно-експресивного забарвлення оригіналу.

У цій розвідці розглядаємо особливості перекладу фразеологізмів, що їх виявляємо в промовах Г. Клінтон. Зазначаємо, що політикиня часто вдається до використання цих мовних одиниць з метою впливу на слухача й досягнення конкретних інтенцій. Фразеологізми $€$ ефективним засобом впливу, що забезпечує прагматичне навантаження промови завдяки їхньому емоційно-експресивному забарвленню, афористичності, лаконізму.

Використання аналога є досить поширеним способом перекладу й таким, що здатний ефективно відтворити прагматику. У наступному прикладі звертаємо увагу на переклад фразеологізму seal the deal: I was leaning toward Yale anyway but that pretty much sealed the deal, and when I came to Yale I was one of 27 women out of 235 law students. Я однак схилялася до Єлю, однак ие було тим, що розставило крапки над “i”, і коли я прийшла до Єлю, то була однією з 27 жінок серед 235 студентів юридичного факультету (Class Day Address at Yale University). Для перекладу виокремленого фразеологізму використано український аналог розставити крапки над “i”, що відтворює прагматику оригіналу. Зазначимо, що ця мовна одиниця увійшла до узусу української мови, однак не є власне українською, оскільки походить із французької.

Переклад фразеологізму є повноцінним й адекватним за умови наявності аналога, порівн.: And particularly to the parents, the spouses, the children, the family members who've helped make this day possible thank you. Yоu are living proof that it really does take a village. - І особливо батькам, чоловікам та дружинам, дітям, членам родин, які зробили 
ией день можливим - дякую. Ви справжній доказ того, що гуртом можна і море загатити (Commencement Address at Hunter College). Для перекладу приказки it takes a village («It takes a village to raise a child») - 'Many people's help or involvement is needed to achieve some goal') (The free dictionary) обираємо український аналог, приказку гуртом можна й море загатити, що за відтворює прагматику оригіналу.

У промові перед випускниками виявляємо фразеологізм lay bare: This pandemic has laid bare some of the biggest social problems facing our country - Пандемія виявила одні з найбільших проблем, перед якими стоїть наша країна. Тут удаємося до лексичного перекладу, що передбачає заміну фразеологізму одиницею, що має ту саму семантику, однак не містить відповідного емоційно-експресивного забарвлення. У цьому разі спостерігаємо втрату прагматики оригіналу, що має бути компенсовано на рівні тексту.

У разі використання часткового еквівалента один із компонентів фразеологізму в мові перекладу є відмінним від оригінального: And here's the second lesson - progress is not a straight line, so don't lose heart. - I ось другий урок - успіх ие не пряма, тож не втрачайте надіï (Commencement Address at Hunter College). У цьому прикладі використовуємо частковий еквівалент для перекладу фразеологізму lose heart і перекладаємо як втрачати надію.

У процесі дослідження виявляємо, що певні фразеологізми $є$ частотними в мовленні Г. Клінтон. Зокрема, неодноразово виявляємо фразеологізм glass ceiling, що в англійській мові має значення 'the attitudes and practices that prevent women or particular groups from getting high-level jobs, even though there are no actual laws or rules to stop them' (Longman Dictionary), порівн.: I know we have still not shattered that highest and hardest glass ceiling, but someday someone will - Я знаю, що ми ще досі не зруйнували ту найвищу, найміцнішу стіну, але одного дня хтось це зробить. У наведеному прикладі фразеологізм glass ceiling перекладаємо за допомогою метафоричного словосполучення руйнувати стіну, що компенсує втрату значення оригінальної одиниці та $є$ більш зрозумілим українцям, оскільки не знаходимо еквівалента, що б містив ідентичний англійському фразеологізму зміст. Тут використовуємо метафору стіна, яку варто зруйнувати.

Привертає увагу інший контекст уживання того самого фразеологізму: After all, when there are no ceilings, the sky's the limit - I нарешті, 
коли перед тобою немає гір, горизонт видно набагато краще (Clinton: «With No Ceilings, The Sky's the Limit»). Тут виявляємо два фразеологізми glass ceiling та the sky is the limit ('used to say that there is no limit to what someone can achieve, spend, win etc') (Longman Dictionary); у першому пропущено компонент glass, однак він лишається впізнаваним носієві англійської мови. Для перекладу пропонуємо такий варіант: коли перед тобою немає гір, горизонт видно набагато краще. Обираємо метафори гори, горизонт, що є більш близькими українській свідомості й мають відповідні конотації - гори часто асоціюються з перешкодами на шляху досягнення цілей, а горизонт $є$ чимось віддаленим, до чого прямує людина. Тут значення оригінальних фразеологізмів компенсовано завдяки метафорам, оскільки ідіома glass ceiling не має еквівалента в українській мові, тому іiі дослівний переклад не дав би можливості досягти інтенцій автора.

В обох проаналізованих вище випадках не вдається знайти ані еквівалента, ані аналога, однак запропоновані варіанти перекладу також містять прагматику завдяки їх метафоричності. До того ж уважаємо, що відсутність еквівалентів та аналогів фразеологізму в українській мові $є$ проявом соціальних моделей поведінки, рівня значущості конкретних питань у суспільстві, зокрема гендерної рівності й боротьби жінок за свої права. Очевидно, що ці питання є більш актуальними та гострими для американської колективної свідомості, що транслюється в мову, а саме віддзеркалюється в семантиці фразеологічної одиниці glass ceiling.

\section{Висновки}

Отже, переклад фразеологічних одиниць є складним процесом, що передбачає відтворення їх емоційно-експресивного й функціонально-стилістичного наповнення. Прагматичний аспект цих одиниць потребує від перекладача обізнаності, досвіду та досконалих знань і мови перекладу, оскільки, перш ніж обрати нефразеологічний переклад, він має пересвідчитися, що в ній не існує фразеологізму з ідентичним чи близьким значенням, і лише після цього удаватися до перекладу нефразеологічного.

Перспектива досліджень полягає в розробці теоретичного інструментарію перекладу фразеологічних одиниць у мовленні видатних постатей сучасності. 


\section{ЛІТЕРАТУРА}

1. Зорівчак, Р. (1983). Фразеологічна одиниия як перекладознавча категорія. Львів: Вища шк. 2. Кунин, А. (1964). О переводе английских фразеологизмов в англо-русском фразеологическом словаре. В Тетради переводчика (с. 3-20). Москва: Междунар. отношения. 3. Commencement Address at Hunter College - May 29, 2019. Узято 3 https://www.youtube.com/watch?v=qQA-Hx5NonA\&list=PLDLQiU qKaml5hhn2mYm7qa7bcQnfMvZ8I\&index=6\&ab_channel=BloombergQuicktake\% 3ANow. 4. Class Day Address at Yale University - May 20, 2018. Узято з https://awpc. cattcenter.iastate.edu/2018/07/06/class-day-address-at-yale-university-may-20-2018/. 5. Clinton: «With No Ceilings, The Sky's the Limit». Узято з https://www.youtube.com/ watch?v=BPRDvVjtR5k\&ab_channel=AssociatedPres. 6. iHeartRadio «Commencement: Speeches for the Class of 2020» Podcast - May 15, 2020. Узято 3 https://awpc.cattcenter. iastate.edu/2020/05/27/iheartradio-commencement-speeches-for-the-class-of-2020podcast-15-may-2020/. 7. Longman Dictionary of Contemporary English. Узято з https:// www.ldoceonline.com/. 8. Hillary Clinton: Glass Ceiling Will Be Shattered Some Day. Узято 3 https://www.youtube.com/watch?v=ZAq8Mvs5I5Q\&ab_channel=BloombergPolitics. 9. Subbotina, V. (2013). Challenges of translating phraseological units. Procedia - Social and Behavioral Sciences, 1477-1492. 10. The free dictionary. Узято 3 https://idioms. thefreedictionary.com/it+takes+a+village.

\section{REFERENCES}

1. Zorivchak, R. (1983). Frazeolohichna odynytsia yak perekladoznavcha katehoriia [Phraseological unit as a category of translation studies]. Lviv: Vyshcha shkola [in Ukrainian]. 2. Kunin, A. (1964). O perevode angliiskih frazeologizmov v anglo-russkom frazeologicheskom slovare [On translation of English phraseological units in English-Russian phraseological dictionary]. In Tetradi perevodchika - Translator's notebooks (pp. 3-20). Moskva: Mezhdunar. otnosheniia [in Russian]. 3. Commencement Address at Hunter College - May 29, 2019. Retrieved from https://www.youtube.com/watch?v=qQA-Hx5NonA\&list=PLDL QiUqKaml5hhn2mYm7qa7bcQnfMvZ8I\&index=6\&ab_channel=BloombergQuicktake\% 3ANow [in English]. 4. Class Day Address at Yale University - May 20, 2018. Retrieved from https://awpc.cattcenter.iastate.edu/2018/07/06/class-day-address-at-yale-universitymay-20-2018/ [in English]. 5. Clinton: «With No Ceilings, The Sky's the Limit». Retrieved from https://www.youtube.com/watch?v=BPRDvVjtR5k\&ab_channel=AssociatedPres [in English]. 6. iHeartRadio "Commencement: Speeches for the Class of 2020» Podcast May 15, 2020. Retrieved from https://awpc.cattcenter.iastate.edu/2020/05/27/iheartradio-commencement-speeches-for-the-class-of-2020-podcast-15-may-2020/ [in English]. 7. Longman Dictionary of Contemporary English. Retrieved from https://www.ldoceonline. com/ [in English]. 8. Hillary Clinton: Glass Ceiling Will Be Shattered Some Day. Retrieved from https://www.youtube.com/watch?v=ZAq8Mvs5I5Q\&ab_channel=BloombergPolitics [in English]. 9. Subbotina, V. (2013). Challenges of translating phraseological units. Procedia - Social and Behavioral Sciences, 1477-1492. 10. The free dictionary. Retrieved from https://idioms.thefreedictionary.com/it+takes+a+village [in English]. 
Карпенко Наталія Анатолї̈вна - кандидат філологічних наук, доцент кафедри філології, перекладу та мовної комунікації, Національна академія Національної гвардії України; майдан Захисників України, 3, м. Харків, 61168, Україна.

Tel.: +38-098-445-17-24

E-mail: karpenko_nataliya08@ukr.net

orcid.org/0000-0003-2922-0384

Karpenko Nataliia Anatolivna - Candidate of Philological Sciences (Ph.D.), Associate Professor at the Department of Philology, Translation and Lingual Communication, National Academy of the National Guard of Ukraine; 3 Zakhysnykiv Ukrainy square, Kharkiv, 61168, Ukraine.

Кудрявцева Алла Петрівна - магістр гуманітарного факультету, Національна академія Національної гвардії України; майдан Захисників України, 3, м. Харків, 61168, Україна.

Tel.: +38-066-844-12-20

E-mail: akudruaha18@gmail.com

Kudriavtseva Alla Petrivna - Master Student at the Faculty of Humanities, National Academy of the National Guard of Ukraine; 3 Zakhysnykiv Ukrainy square, Kharkiv, 61168, Ukraine.

Надійшла до редакції 12 березня 2021 року

\section{CITATION}

ДСТУ 8302:2015: Карпенко Н. А., Кудрявцева А. П. Відтворення прагматики фразеологізмів в англо-українському перекладі. Лінгвістичні дослідження: зб. наук. пр. Харк. нац. пед. ун-ту імені Г. С. Сковороди. Харків, 2021. Вип. 54. Ч. ІІ. С. 201-208. DOI: https://doi.org/10.34142/23127546.2021.54.2.18

APA: Карпенко, Н. А., \& Кудрявцева, А. П. (2021). Відтворення прагматики фразеологізмів в англо-українському перекладі. Лінгвістичні дослідження, 54 (II), 201-208. DOI: https://doi.org/10.34142/23127546.2021.54.2.18 